\title{
La documentación de la guerra de la antigua Yugoslavia a través de las fotografías de Gervasio Sánchez
}

\author{
Julia R. CELA \\ jurodrig@ccinf.ucm.es \\ Alicia PARRAS PARRAS \\ aparras@ccinf.ucm.es \\ Sección departamental de Biblioteconomía y Documentación \\ Facultad de Ciencias de la Información, Universidad Complutense de Madrid
}

Recibido: 03/06/2012

Aceptado:18/06/2012

\begin{abstract}
Las fotografías que Gervasio Sánchez tomó del conflicto de los Balcanes a partir de 1991, es decir, prácticamente desde que estalla, hasta que finaliza en el año 1999 tras el último enfrentamiento en Kosovo son una gran fuente de información para entender la vida y la respuesta a la guerra que dieron las víctimas, especialmente en los días del cerco a Sarajevo. A lo largo de este artículo veremos el modo en el que la fotografía sirve de documentación para no olvidar que detrás de cada error histórico se encuentran miles de personas que tendrán que convivir con el peor de los horrores: la guerra. También se tratará cómo la vuelta del fotógrafo dieciséis años después, al lugar exacto en el que tomo algunas de sus más impactantes instantáneas cierra el círculo de una de las más importantes labores de información gráfica y documentación de nuestros días.
\end{abstract}

Palabras clave: Gervasio Sánchez, fotoperiodismo de guerra, documentación fotográfica, Cerco a Sarajevo, Guerra de Yugoslavia.

\section{The documentation of the war in the former Yugoslavia through the photographs of Gervasio Sánchez}

\begin{abstract}
The photos that were taken by Gervasio Sánchez at Balcanic conflict from 1991 until 1999 (Kosovo's war, which was the last confrontation) are, nowadays, a great information source in order to understand how was life in that difficult moment and the response given by the victims, especially in the siege days. Throughout this article we will see how photography serves as documentation to remember that behind every historical error are thousands of people who have to live with the worst horrors: war. Also, the return of Gervasio Sánchez to the place where he took the most impressive photos means close the loop of one of the most important graphic works of our time.
\end{abstract}

Key words: Gervasio Sánchez, war photojournalism, photographic documentation, Siege of Sarajevo, Yugoslavia war. 


\section{INTRODUCCIÓN}

El arte de la fotografia fue vital para el periodismo, como muy bien dijo Giséle Freund la fotografía abría una ventana al mundo que cambió la visión de las masas, el hombre común ya no solo visualizaba lo que tenía a su alrededor, ya podía conocer a los personajes públicos, los acontecimientos que ocurrían en el planeta y entre ellos aquellos que producen dolor, como las guerras. ${ }^{1}$ De los primeros conflictos bélicos fotografiados de mediados del siglo XIX, hasta nuestros días, los fotoperiodistas han estado en primera línea para ofrecernos aquellas instantáneas que mejor nos informen de lo que está aconteciendo en el lugar de los hechos, y así también ocurrió en el conflicto bélico de la antigua Yugoslavia, los reporteros gráficos en competencia con la televisión produjeron fotografías que hoy forman parte de nuestro imaginario colectivo, imágenes imborrables que conservamos en nuestra memoria, como la fotografía de Gervasio Sánchez de la destrucción de la Biblioteca de Sarajevo.

Cuando Susan Sontag escribe uno de los últimos libros publicados en vida, Ante el dolor de los demás, en su retina y en su conciencia se encontraban presentes a la hora de escribir este libro, las imágenes del dolor vivido en Sarajevo como testigo presencial de una de las últimas masacres acontecidas en el siglo XX. Ella pudo comprobar sobre el terreno como una guerra que nos parece un hecho real, como cualquier otro, hoy en día se ha convertido en mediática. Algunos intelectuales que pasaron por Sarajevo "llegaron a afirmar que la victoria o derrota bélica no dependía en absoluto de lo que sucediera en Sarajevo, o de hecho en Bosnia, sino de lo que sucediera en los medios." Lo que nos lleva a la terrible afirmación de que cada vez más la guerra es considerada un espectáculo de masas. Durante todo el conflicto de la guerra de Bosnia, los habitantes conocedores de la importancia mediática querían que su situación quedara plasmada en las fotografías, las víctimas en muchas ocasiones se muestran interesadas en la representación de su propio sufrimiento, un sufrimiento que sienten como único y que el espectador debe conocer.

\section{COMPRENDER EL ÚLTIMO GRAN CONFLICTO DEL SIGLO XX EN EUROPA ¿POR QUÉ UNA GUERRA TAN CRUEL A LAS PUERTAS DEL SIGLO XXI?}

Y la pregunta obligada que nos hacemos es cómo en los umbrales del siglo XXI se pudo vivir tanto sufrimiento, cuál fue la causa que produjo tanto dolor humano. Y para obtener una respuesta tenemos que acudir a los últimos acontecimientos históricos causantes del conflicto. Es un lugar común que el área de los Balcanes genera más

${ }^{1}$ FREUND, Gisèle. La fotografía como documento social. Barcelona, Gustavo Gili, 1976.

${ }^{2}$ RODRÍGUEZ CELA, Julia y PARRAS PARRAS, Alicia. "El tratamiento documental en la fotografía de prensa: ante el dolor de los demás y el conflicto de los otros". Revista General de Información y Documentación, Vol. 20, 2010, p. 466. 
historia de la que sus habitantes son capaces de asumir, y es cierto, que el último siglo comenzó con un atentado fatídico en Sarajevo que provocó la Primera Guerra Mundial y terminó también en Sarajevo con el conflicto bélico que desmembró a la antigua Yugoslavia.

Después de la caída del muro de Berlín en 1989, fueron cayendo también los gobiernos del socialismo, pero quedaba un caso por resolver la Yugoslavia que había mantenido unida, Josip Broz "Tito", una República Federal integrada por seis repúblicas: Serbia, Croacia, Eslovenia, Bosnia-Herzegovina, Montenegro y Macedonia, así como las regiones autónomas de Vojvodina y Kosovo. Como en la mayoría de los conflictos todo comenzó por una aguda crisis económica, que trajo consigo un alto índice de paro y el malestar social que agudizó las tensiones separatistas, ya latentes desde la muerte de Tito.

En Serbia la desintegración de la Liga de los comunistas (nombre que recibe el Partido Comunista yugoslavo) produce un caos político que aprovecha Slobodan Milosevic para fundar el Partido Socialista de Serbia, con el que alcanza en 1997 la presidencia federal de la República yugoslava, y su ascenso consiguió alentar el nacionalismo popular serbio. ${ }^{3}$ La separación de Eslovenia fue de las seis repúblicas la más sencilla, ya que es una zona de predominio étnico de los eslovenos, que son el $88 \%$ de la población, y que además tenían una lengua propia, diferenciada del serbocroata, por lo que en diciembre de 1990 un plebiscito con un resultado aplastante a favor de la independencia hizo posible que se proclamara esta, el 25 de junio de 1991.

En el caso de Croacia pese al apoyo internacional, la situación no fue tan fácil, ya que en ella se encontraban un $12 \%$ de población serbia que exigía que sus derechos fueran respetados. De modo que cuando los croatas proclaman su independencia comienzan los combates en aquellas poblaciones de mayoría serbia, iniciándose una guerra que causaría más de 20.000 muertos hasta el alto el fuego de enero de 1992. Los combates en la región de Krajina de mayoría serbia se reanudaron de 1993 a 1995, lo que causó la muerte de millares de personas de origen serbio y el desplazamiento de otras 200.000. Croacia se encontraba gobernada por Franjo Tudman uno de los antiguos generales del ejército yugoslavo de ideología nazi, que quería establecer el nuevo orden europeo de Hitler. "Tudman, que se rodeó de antiguos nazis, falseó las elecciones, permitió una limpieza étnica brutal y estimuló una renovación espiritual en colaboración con la iglesia católica, murió en su cama en 1999, dejando tras de sí un legado de corrupción."

En 1992 se proclama la independencia de Macedonia, protegida por los Estados Unidos y vetada por Grecia.

La Unión Europea también alentaba la independencia de otra de las repúblicas, la de Bosnia-Herzegovina, seguramente la más conflictiva, y desde luego compleja, pues en

3 FONTANA, Josep. Por el bien del Imperio. Una historia del mundo desde 1945. Barcelona, Ediciones de Pasado Presente, 2011, pp. 794-803.

${ }^{4}$ Ibídem, p. 796 
ella habitaban las tres etnias: un $44 \%$ de musulmanes, un $31 \%$ de serbios y un $12 \%$ de población croata. En febrero de 1992 se impone un referéndum que arrojó una mayoría absoluta a favor de la independencia. Cuando la independencia es efectiva y reconocida por la UE y EEUU, en abril de 1992 fuerzas paramilitares serbias al mando de Ratko Mladic comienzan a bombardear Sarajevo iniciando así una de las guerras más cruentas de limpieza étnica del siglo XX, ante la mirada de millones de espectadores y la pasividad de Occidente. La situación permaneció confusa y mal gestionada por las potencias occidentales, hasta que en julio de 1995 se produce la brutal matanza de 7.500 musulmanes por parte de los serbios en Srebrenica, (imágenes que impresionaron al mundo), a la que siguió otras de 3.000 personas en Zepa y 4.000 en Banja Luka. Estos sucesos obligaron a intervenir a las fuerzas de la OTAN, para declarar un alto el fuego en octubre y firmar el 14 de diciembre de 1995 los acuerdos de Dayton, "que creaban una república federal bosnia integrada por dos entidades autónomas la Federación musulmano-croata, que ocuparía el 51 por ciento del territorio, y la República Srpska, con el 49 por ciento. La nueva entidad federal tendría un gobierno establecido en Sarajevo, con dos cámaras y tres presidentes (serbio, bosnio y croata), aunque de hecho el nuevo país seguiría siendo una especie de protectorado de las Naciones Unidas, con un Alto representante que tendría autoridad ejecutiva sobre las dos comunidades."

Aunque el acuerdo de Dayton supone el final de la guerra de Bosnia, el conflicto en la antigua Yugoslavia todavía continua, queda la región de Kosovo, en la que los kosovares ya hace años habían iniciado movimientos de resistencia pasiva, que se agudizan en abril de 1996 cuando se produjo el primer atentado terrorista perpetrado por un grupo kosovar, que fue el comienzo de una guerra abierta que se agudiza en 1998, con la muerte de 3.000 kosovares y el desplazamiento de 300.000 , lo que ya obliga a la intervención del Consejo de Seguridad de la ONU que exigió un alto el fuego e inició las negociaciones de paz, entre serbios y kosovares que se concretaron en la firma de los acuerdos de Rambouillet y París en marzo de 1999. La guerra llegaba a su fin, y el 17 de febrero de 2008, se proclamaba la independencia de la región de Kosovo, constituyéndose en lo que los kosovares denominaron una república democrática, laica y multiétnica. Ya anteriormente en el año 2006, la república de Montenegro también había proclamado su independencia, lo que significaba el final del estado de Yugoslavia.

Los historiadores con la perspectiva que nos ofrece el tiempo nos cuentan los hechos, pero son los escritores quienes en muchas ocasiones perciben estos, a través de la observación de sus semejantes y gracias a la sensibilidad que les otorga una mirada lúcida de lo que está ocurriendo ante sus ojos, son quienes nos ofrecen las primeras imágenes, las primeras instantáneas gracias a la palabra y en muchos casos son precursores de los hechos históricos que están por acontecer.

${ }^{5}$ Ibídem. p. 799 
Dos escritores de aquella antigua Yugoslavia que no vivieron su desmembramiento pero que sí nos lo anticiparon en sus libros, fue el premio nobel de Literatura Ivo Andric y el escritor Danilo Kis. Ivo Andric nació en Bosnia-Herzegovina aunque era de ascendencia serbia. Pasó su infancia en la ciudad bosnia de Visegrad a orillas del río Drina en la frontera con Serbia, lo que le sirvió de inspiración para componer su novela mas conocida Un puente sobre el Drina, con la que obtuvo en 1961, el Premio Nobel de Literatura. En Visegrad se construye en la Edad Media un puente que enlaza el mundo cristiano con el mundo islámico, que tan bien se refleja en la novela, la convivencia de las distintas etnias que pueblan la ciudad: cristianos, judíos y musulmanes, en la larga crónica que abarca desde el siglo XVI hasta principios del S.XX, y así tomando como hilo conductor el puente que cruza el río narrarnos las pequeñas historias particulares de los habitantes de la ciudad, a través de las sucesivas generaciones que forman esta comunidad de la antigua Yugoslavia y que nos muestra las raíces del odio y la violencia que se ha ido fraguando a través de los siglos, y nos explica lo que tuvo lugar en la última década del siglo XX. ${ }^{6}$

El otro escritor que nos narra lo que sucedió con Yugoslavia es Danilo Kis, nacido en Serbia en 1935, y fallecido en París en 1989. Danilo Kis reúne en su propia biografía lo que significó la antigua Yugoslavia, nacido en Serbia pero de padre judío y madre montenegrina, cuyo padre al igual que otros miembros de la familia murieron en los campos de exterminio; él fue un ciudadano del mundo, que vivió en Belgrado, en Hungría, Montenegro y sobre todo, en París. En su novela Una tumba para Boris Davidovich, nos encontramos con un prólogo del Nobel de literatura Joseph Brodsky, escrito para la edición americana en 1980, que nos explica las razones que se encuentran en el ambiente y en las gentes de la antigua Yugoslavia, que desembocarán una década después en un conflicto bélico.

"Con independencia de las razones geopolíticas generales, la ideología desempeña un importante papel en la vida de Yugoslavia, pues este pequeño país es una república federal en más de un sentido. Alberga una docena de nacionalidades con el correspondiente número de creencias religiosas, grupos étnicos, y una serie de partidos políticos impotentes, con la Unión de Comunistas Yugoslavos a la cabeza. Huelga decir que todos estos grupos nacionales tienen un montón de cuentas -viejas y nuevas- por saldar. Toda postura ideológica esta por ende visiblemente teñida de nacionalismo, y viceversa. La acusación de distorsionar la verdad histórica puede ocultar una nostalgia paneslávica, un comentario antisemita resulta una manera velada de enunciar el sueño secesionista, y a veces la única forma que tiene un macedonio de expresar su antipatía hacia un montenegrino es acusarlo de revisionismo. En

\footnotetext{
${ }^{6}$ ANDRIC, Ivo. Un puente sobre el Drina. Madrid, Debate, 1999.
} 
otras palabras: toda acusación formal no es más que la punta de un enorme iceberg de odio real. ${ }^{7}$

Ya nos quejamos de la pasividad de las potencias occidentales ante un conflicto que tenían ante sus propios ojos, en un lugar nada lejano, en la vieja Europa, a unas horas tan solo de avión de las principales capitales del mundo. También los pocos intelectuales que acudieron a Sarajevo se quejan de la pasividad de sus colegas, a diferencia de la Guerra Civil española que atrajo a gran número de intelectuales de todo el mundo y a combatientes de más de 35 países, en la antigua Yugoslavia ocurrió lo contrario, apenas se desplazaron a las zonas de conflicto, tampoco elevaron sus voces para denunciar las masacres étnicas que todos presenciamos gracias a las imágenes que nos suministraron a través de la televisión y las fotografías. Una de las pocas intelectuales que acudió a Sarajevo, fue la escritora norteamericana Susan Sontag, quién así nos expresa su decepción ante la actitud de los intelectuales en una entrevista concedida al periodista Alfonso Armada: "Respecto a la actitud de los intelectuales, me parece penosa... Cuando salí de aquí -se refiere a Sarajevo- en abril sugerí a todo el que encontré que viniera a Sarajevo. De la larga lista de famosos con los que hablé, sólo dos respondieron: uno se acaba de ir, es Juan Goytisolo, al que admiro de corazón; la otra Annie Leibovitz, una fotógrafa muy conocida, que todavía está aquí. Muchos me dijeron: "Oh, es peligroso", o "tú debes estar loca", o "es muy triste". Y ante una situación tan desesperada que vivió Susan Sontag en Sarajevo, qué podía hacer en una ciudad que estaba siendo bombardeada, tal vez sólo llevar un ápice de esperanza, y así lo hizo montando la obra teatral de Samuel Becket: Esperando a Godot, una obra muy apropiada con lo que estaban viviendo los habitantes de Sarajevo.

Otro de los intelectuales que también acudió a Sarajevo fue el escritor español, Juan Goytisolo, quién nos explica con estas palabras qué fue lo que le impulsó a acudir a Sarajevo, en un momento muy dramático, en el que la ciudad estaba siendo bombardeada. "Cuando empezó la implosión de Yugoslavia y la guerra en Bosnia, ya había leído el manifiesto de los intelectuales de la Academia de Ciencias de Belgrado que sirvió de base, al programa de Milosevic para practicar lo que se ha llamado la limpieza étnica. Al leer este documento, me sorprendió el paralelo entre los mitos en los que se fundaba el ultranacionalismo serbio y los mitos en los que se fundó durante siglos el ultranacionalismo español. (...) En mayo de 1993 encontré en Berlín a Susan Sontag que acababa de regresar de Sarajevo. "Tienes que ir", me dijo, "es impensable lo que está ocurriendo en una ciudad europea sin que haya una movilización cívica o una protesta por parte de los intelectuales". Le dije inmediatamente que sí, y en julio fui por primera vez a Sarajevo durante uno de los momentos más duros del asedio. El resultado

${ }^{7}$ KIS, Danilo. Una tumba para Boris Davidovich. Prólogo de Joseph Brodsky. Barcelona, Acantilado, 2006, pp. 10-11.

${ }^{8}$ Entrevista de Alfonso Armada: "El siglo XXI comienza con el sitio de Sarajevo". El País, 25 de julio de 1993. 
fue el Cuaderno de Sarajevo." " Un libro en el que nos narra lo que ocurrió en aquellos días del sitio de Sarajevo, así como el encuentro que tuvo con los personajes que vivían como él ese drama cotidiano: los francotiradores, los burócratas de las Naciones Unidas, los líderes religiosos musulmanes, su amiga Susan Sontag, los periodistas, los fotógrafos, etc. ${ }^{10}$ Además de este libro de crónicas periodísticas que se publicaron en el diario El País, Juan Goytisolo también escribió una novela: El sitio de los sitios, inspirada en la experiencia de Cervantes, un Cervantes cautivo, pero esta vez en Sarajevo. El título semítico El sitio de los sitios, nos recuerda de alguna manera a El cantar de los cantares, y en ella el autor quería hacer sentir a los lectores lo que estaban sintiendo y padeciendo los habitantes de Sarajevo, sometidos a una serie de círculos concéntricos que así nos los explica el autor: "El primer círculo fue el mortífero ataque de los extremistas serbios; el segundo, el de la UNPROFOR, la llamada Fuerza de Protección de las Naciones Unidas, cuyos elementos en realidad estaban allí solamente para mantener el status quo, es decir el bombardeo continuo, sin establecer ninguna distinción entre verdugos y víctimas, entre la gente que defendía un estado de ciudadanos y los extremistas que peleaban por una causa puramente racista y ultranacionalista; el tercero, la tergiversación y el silencio de los medios informativos". ${ }^{11}$ Como vemos Juan Goytisolo se muestra muy crítico por un lado con la intervención de la ONU, y por otro, con los medios de comunicación que en muchos casos guardaron silencio, y en otros, tergivesaron la información.

Los periodistas y reporteros gráficos que estuvieron en la guerra de Bosnia coinciden en que pudieron moverse con libertad absoluta, que no les pusieron límites, y que tal vez por ello, tantos periodistas perecieron intentando realizar su trabajo. También coinciden al señalar que los medios de comunicación han sido el instrumento a través del cual los políticos ultranacionalistas han arrastrado a su pueblo a una guerra que no quería, los medios de comunicación de la antigua Yugoslavia contribuyeron a crear el ambiente propicio para la guerra, y a alentar los odios étnicos que ya venían de atrás. "En la antigua Yugoslavia la manipulación de los medios ha contribuido decisivamente a romper la convivencia de una sociedad multiétnica, pluricultural y plurireligiosa. En la década de la guerra como espectáculo en la salita de estar, de bombardeos que nos recuerdan "los arbolitos de Navidad" (Irak 91) y desembarcos a los que llega antes la CNN que las tropas norteamericanas (Somalia 92), la guerra de Bosnia pone en evidencia que, a menudo, los medios no explican los conflictos, sino que los refuerzan". ${ }^{12}$ Los medios en muchas ocasiones, y esto se ha visto claro en la

9 Entrevista de Rubén Gallo a Juan Goytisolo. "El intelectual ante el memoricidio" en Vuelta, n $^{\circ} 253$, diciembre, 1997, p. 32.

10 GOYTISOLO, Juan. Cuaderno de Sarajevo. Anotaciones de un viaje a la barbarie. Madrid, El País-Aguilar, 1993.

${ }^{11}$ Entrevista de Rubén Gallo a Juan Goytisolo. "El intelectual... Op. Cit., p. 33.

12 "Como se construye una guerra". Publicado en Viejo Topo, núm. 72. http://www.uv.es/almiyan/armengou.html (26-06-2012) 
guerra de Bosnia en un universo de fanatismo e histeria colectiva, son responsables a la hora de transmitir su información sobre el conflicto.

Pero no todos los periodistas nos ofrecieron una versión manipulada o tergiversada de los hechos, muchos intentaron mostrarnos lo que veían sus ojos, y sobre todo los reporteros gráficos que con sus imágenes dieron fe del dolor humano y de la destrucción. Uno de esos reporteros gráficos fue Gervasio Sánchez, que publicó fotos memorables sobre Sarajevo que se recogen en su libro: Sarajevo 1992-2008, en la que se encuentra una foto que dio la vuelta al mundo y que hoy es un símbolo de la destrucción y la desolación que produjeron las bombas en la ciudad de Sarajevo, nos referimos a la foto que muestra el bombardeo de la Biblioteca de Sarajevo, y que así nos la describe, Juan Goytisolo:

"La imagen tomada por Gervasio Sánchez capta perfectamente el cuadro de horror y desolación del lugar. El domingo 26 de agosto de 1992, los ultranacionalistas serbios arrojan sobre el Instituto de Estudios Orientales -la célebre biblioteca de Sarajevo- un diluvio de cohetes incendiarios que redujeron en pocas horas a cenizas su rico patrimonio cultural. Fue un memoricidio más en la lista de los que jalonan en la historia inhumana de la humanidad. Puesto que toda huella otomana debía de ser borrada del territorio de la Gran Serbia soñada de Milosevic, Karadzic y Mladic... La biblioteca, memoria colectiva del pueblo musulmán bosnio, estaba condenada a perecer en las llamas de la vengadora purificación. Cuando la fotografió Gervasio Sánchez, conservaba sólo las cuatro fachadas neomoriscas, restauradas hoy con la ayuda del Ministerio de Cultura español. El armazón metálico de la cúpula de vidrio por la que cayeron los cohetes parecía una gigantesca telaraña por la que se filtraba la luz, los soportales del patio interior mostraban apenas su fina labor de yesería, el espacio central era un montón ingente de escombros, cascotes, vigas, paneles chamuscados. Pero, como dijo un poeta a sus inquisidores, "podéis quemar mis libros más no el espíritu que contienen". ${ }^{13}$

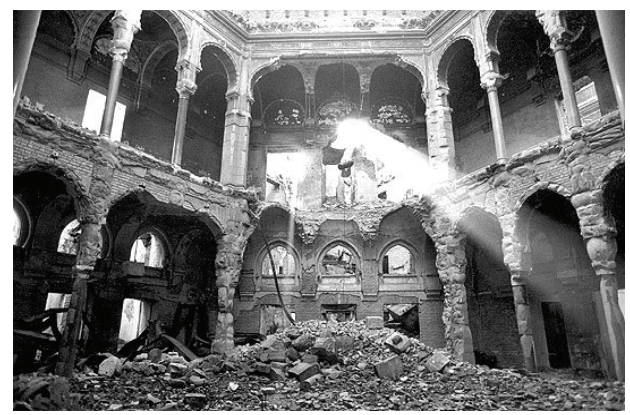

Biblioteca de Sarajevo

${ }^{13}$ Artículo de Juan Goytisolo publicado en El País, 12-06-2012. 


\section{MEDIATIZACIÓN, BANALIZACIÓN Y COTIDIANEIDAD DEL SUFRIMIENTO EN EL DÍA A DÍA DEL CERCO A SARAJEVO}

La guerra de la antigua Yugoslavia fue una guerra totalmente mediatizada en los albores del siglo XXI: no hubo medio de comunicación que no estuviese presente en los horribles combates y bombardeos que tuvieron lugar. Desde Vietnam no se había asistido a la visión del dolor ajeno en un conflicto bélico tan de cerca y tan de lejos; de hecho, el pasado seis de abril de 2012 se cumplieron veinte años desde su inicio pero apenas los medios se hicieron eco y mucho menos la casta política. Los habitantes del Viejo continente contemplamos sin atisbo de sonrojo la última gran masacre del siglo. Los televisores cumplieron a la perfección su papel y eran continuas las imágenes de aquella lucha pero ¿por qué el dolor de aquellas víctimas dejó de impresionarnos? ¿por qué a veces conviene mostrar la lucha y no sus consecuencias en cuanto al daño humano? Susan Sontag, testigo privilegiado en aquel conflicto $^{14}$, recoge en su libro Ante el dolor de los demás el testimonio de una habitante de Sarajevo que en 1991 vio por la televisión la destrucción por parte de los serbios de la ciudad croata de Vukovar, a tan sólo trescientos kilómetros de su ciudad; simplemente pensó ;Qué terrible! y cambió de canal. Dondequiera que la gente se sienta segura, sentirá indeferencia ${ }^{15}$ confesó a la autora durante la estancia de esta en 1993 en Sarajevo.

Al igual que ocurrió con la pasividad de los gobiernos internacionales incapaces de encontrar una solución que pusiese el freno a la atrocidad de lo que estaba sucediendo en aquel momento en los Balcanes, los espectadores asistieron a lo que hoy podemos llamar la banalización del dolor y que fue resultado de la mediatización del conflicto. Margaret Bourke-White relata que cuando fue una de las primeras fotoperiodistas al entrar en un campo de concentración, concretamente el de Buchenwald, tras la victoria alemana y ver el horror de miles de cuerpos amontonados en el suelo sintió el alivio de llevar la cámara de fotos que actuaba como elemento de separación entre la dura realidad y su ojo. ${ }^{16}$ No obstante, hoy, aquella icónica imagen de los supervivientes de aquel campo, de los esqueletos humanos mirando fijamente al objetivo de la cámara, mil veces vista ha dejado de impresionarnos como a aquellos fotógrafos y cómo nos impresionó la primera vez que la vimos; evidentemente se trata del anteriormente citado concepto de banalización: el dolor mil veces visto en una imagen ya no es dolor, no impresiona, es una fotografía más. Millones de horribles imágenes que llegan a la retina de un espectador ávido al principio, pero hastiado después, por el carnaval de horrores que

${ }^{14}$ Susan Sontag estuvo varias veces en Sarajevo entre 1993 y el fin del conflicto. Incluso estrenó allí una nueva versión del clásico de Beckett "Esperando a Godot".

${ }^{15}$ SONTAG, Susan: Ante el dolor de los demás. Santillana, Madrid, 2007, p. 116.

${ }^{16}$ BOURKE-WHITE, Margaret: Dear Fatherland, rest quietly: a report on the collapse of Hitler's "thousand years” New York .Simon and Schuster, 1946 
ve al encender su televisor y que vuelve a observar en las numerosas fotografías que inundan los periódicos. Poco llegamos a comprender de aquel conflicto y mucho menos conocemos ahora.

La banalización puede ocurrir en cualquier medio, en cualquier soporte: fotografías que ilustran la portada del periódico de hoy o la sucesión de las mismas emitidas en el telediario. En cualquier caso, en el presente artículo nos centraremos en la fotografía pues como dice Susan Sontag el conjunto de imágenes incesantes (la televisión, el video continuo, las películas) es nuestro entorno pero a la hora de recordar, la fotografía cala más hondo. La memoria congela los cuadros; su unidad fundamental es la imagen individual. En una era de sobrecarga informativa, la fotografía ofrece un modo expedito de comprender algo y un medio compacto de memorizarlo. La fotografía es como una cita, una máxima o un proverbio. Cada cual almacena mentalmente cientos de fotografias sujetas a la recuperación instantánea. ${ }^{17}$ Es por eso fundamental hoy la obra fotográfica de Gervasio Sánchez en torno al cerco de Sarajevo. Comprender un conflicto de la magnitud del bosnio supone conocer agentes como la historia, la literatura, la sociedad, los nacionalismos y la política de la antigua Yugoslavia, pero también conocer sus gentes, las relaciones interpersonales, su sufrimiento y por tanto su vida inmersa en la guerra. Mientras que las imágenes emitidas en los telediarios de todo el mundo apenas nos han dejado rastro en la memoria, las fotografías de Gervasio Sánchez están grabadas en nuestras retinas y aún hoy nos hacen reflexionar.

A partir de ahora se inicia un recorrido fotográfico por el Sarajevo en guerra: un Sarajevo contradictorio de sentimientos enfrentados y convivencias truncadas, donde el día a día prosigue a pesar de la horrible lucha, y un Sarajevo que hoy apenas ha olvidado las heridas causadas tras tantos años de enfrentamiento entre etnias y la incomprensión y pasividad internacional. Gervasio Sánchez es no solo un fotoperiodista sino todo un documentalista que nos ha permitido mirar, veinte años después, por una ventana la vida de los habitantes atrapados en el cerco o presos en régimen abierto como señala Juan Goytisolo. ${ }^{18}$

En el libro, setenta y seis fotografías son las pruebas irrefutables de lo que en Sarajevo se vivió. La mayoría hablan de la cotidianeidad, es decir, de ese día a día dentro del infierno: conseguir agua aún a sabiendas de que se puede morir en el intento, pasear una tarde soleada con el consiguiente peligro de que un francotirador dispare. Pero también son cotidianos los entierros a las 11 de la mañana, los cementerios que antes eran parques, los soldados esperando a que una señal enemiga le haga disparar su arma, los hospitales e incluso los desórdenes mentales que el cerco ha causado en los habitantes de la ciudad y que no son de extrañar al convivir con el estrés de la amenaza de muerte continua durante aproximadamente tres años. Según el testimonio del presidente de la Asociación Bosnia de Psiquiatras, Slobodan Loga, las

${ }^{17}$ SONTAG, Susan: Ante el dolor ...., Op. cit. p. 116.

${ }^{18}$ GOYTISOLO, Juan: Cuaderno de Sarajevo... Op.cit .p. 28. 
enfermedades mentales se multiplicaron por diez durante la guerra; los trastornos psicóticos agudos se multiplicaron por cinco; los trastornos debidos al alcohol disminuyeron porque no era posible encontrar bebidas alcohólicas en la ciudad. [...] Respecto a los problemas futuros de los que durante la guerra eran niños, yo creo, y me gustaría mucho equivocarme, que en el futuro se incrementará el nivel de psicóticos entre los adolescentes y entre los adultos. El trauma sigue trabajando en sus cabezas, no ha desaparecido. ${ }^{19}$ Según el propio Gervasio Sánchez el estrés postraumático ha sido el verdadero lastre de la posguerra: Para mi la guerra se acaba cuando las consecuencias se superan. Pase el tiempo que pase. Entonces esas personas que tu ves en ese reportaje que parecen que han sido preguntados sobre algo que pasó ayer pero que en realidad ha pasado hace veinte años, nunca han sido valorados por un psicólogo ni por un psiquiátra. ${ }^{20}$ Mientras que los edificios son reconstruidos, los suicidios son parte del día a día en una ciudad donde a nadie, en palabras también de Gervasio Sánchez, le ayudaron a resolver su drama.

Muchas fotografías que forman parte de Sarajevo: El cerco, pueden encuadrarse en distintas categorías, aunque como ya se ha señalado, la mayoría responden a la cotidianidad. Otras muchas se corresponden con los paisajes desolados de la ciudad inmersa en la guerra: casas destruidas, señales que son cicatrices en los edificios bombardeados y también pinturas reivindicativas como en la fotografía 2 "Welcome to hell" o la 24 "Born in Bosnia", es decir, por encima de la religión o la etnia está el hecho de nacer en Bosnia como único rasgo valido distintivo y aglutinador de los habitantes.

La atención del fotógrafo se centra también en los más desvalidos, es decir, en los niños y en los ancianos. De los primeros vemos fotos que tristemente se nos clavan en la memoria, de esas que saltan automáticamente cuando nos dicen "Bosnia" o "Sarajevo" y que difícilmente se borran. Se trata de la foto del bebé de dos meses llamado Nalena Skorupan fallecida junto a su tía Mirsada por las heridas causadas tras el bombardeo del seis de enero de 1994. Otros niños, casi tres mil, no correrán mejor suerte y serán acribillados cuando salen en busca de pan y agua. Quizá es cierto lo que a Juan Goytisolo le contaron en el hospital de Kosovo y los chetnicks sean recompensados con una prima doble por cabeza de mujer y quíntuple por alcanzar a un niño. ${ }^{21}$ Lo cierto es que probablemente el espectador inmerso en el océano de fotografías de una y otra guerra se sienta más conmovido con aquellas imágenes que nos muestran trágicamente el sufrimiento infantil. En cualquier caso ello se debe a que los niños nunca son quienes originan las guerras y en cambio pueden ser sus

${ }^{19}$ NAVARRO, Pepe: Sarajevo humano. Palabras, retratos e imágenes. 111 entrevistas a sus habitantes después de la guerra. Barcelona. Blume, 1999.

${ }^{20}$ Entrevista inédita realizada por Alicia Parras a Gervasio Sánchez en Aranjuez el 2 de julio de 2012.

${ }^{21}$ GOYTISOLO, Juan: Cuaderno de Sarajevo... Op. cit., p. 35 
principales víctimas ${ }^{22}$. Gervasio Sánchez apenas muestra muertos en sus fotos pero, casualmente, las únicas fotografías de cadáveres son dos niños: Nalena y Nermín.

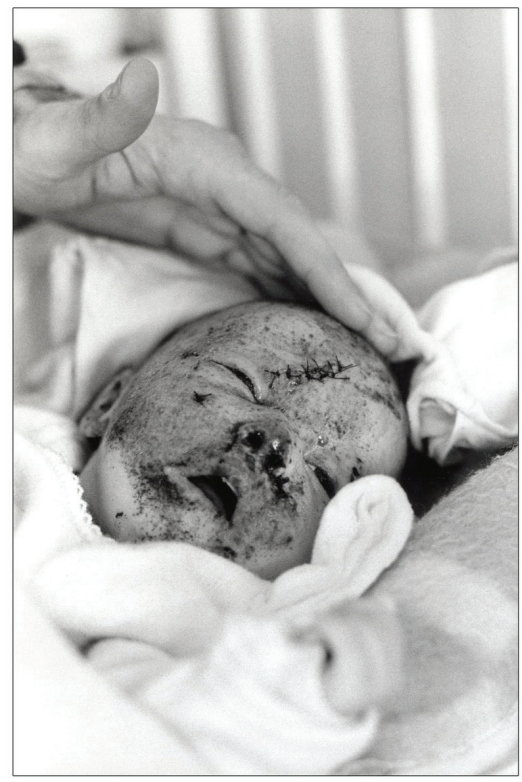

Nalena Skorupan

De los ancianos, las fotografías son aún más conmovedoras si cabe. Ancianos como Gabriela Matz, que en 1993, tenía 83 años y había sido testigo de tres guerras acontecidas en los Balcanes: la I Guerra Mundial, la II Guerra Mundial y la Guerra de la Antigua Yugoslavia en los 90. Pese a la vivencia de tal cantidad de conflictos, esta anciana en cuyas venas corría sangre croata, austriaca y católica bosnia seguía sin entender la naturaleza de la guerra aunque tenía claro que sin ninguna duda su vivencia más dura fueron los más de mil días que vivió dentro del cerco que asedió a Sarajevo. Pudo haber pasado esta última guerra en Split, una ciudad costera de Croacia junto a una hermana pero prefirió quedarse en su querida ciudad Sarajevo, en una de las habitaciones de su casa bebiendo café, fumando tabaco y haciendo un puzzle de 4000 piezas casi tan complicado como el mismo conflicto. ${ }^{23}$

22 RODRIGUEZ CELA, Julia y PARRAS, Alicia: El tratamiento documental en la fotografia de prensa..., Op. cit., P. 466

${ }^{23}$ SÁNCHEZ, Gervasio: Con el cerco de Sarajevo en el alma. Texto y fotos. Publicado en www.magazinedigital.com 11/01/2009. 


\section{SARAJEVO AYER Y HOY: LA MEMORIA DEL DOLOR. LAS FOTOGRAFÍAS DE GERVASIO SÁNCHEZ COMO DOCUMENTO ATEMPORAL DEL SUFRIMIENTO DE LAS VÍCTIMAS.}

Hace 20 veinte años estallaba el conflicto en los Balcanes. Un conflicto que en opinión de muchos continúa latente en Bosnia porque el dolor que han dejado las heridas de un conflicto tan largo en la memoria colectiva del pueblo es imposible de olvidar. Cuando una guerra acaba, las víctimas, los que han presenciado el horror, lo único que buscan es dejarlo atrás pero ¿conviene olvidar? ¿es necesario tener presente la causa del conflicto para no volver a repetir esos mismos errores?

Según el analista Momir Dejanovic los temas nacionales son los dominantes en las elecciones, y todos los demás problemas de la vida, los asuntos sociales, de desarrollo, democráticos y otros han sido descuidados. Además el sistema creado tras el fin de la guerra es aún demasiado burocrático, según Gervasio Sánchez, se ha creado una estructura político-económica imposible de sostener. Hay tres parlamentos, hay tres gobiernos, hay dos administraciones distintas. Eso es imposible de sostener económicamente y eso no se va a solucionar al menos que alguien tome la decisión férrea de acabar con tanta burocracia. ${ }^{24}$ Parece que el pueblo bosnio, o mejor dicho, sus gobernantes han sido incapaces de continuar su propia historia que no es otra que la de la multietnicidad. Además, los serbios, musulmanes y croatas viven separados en términos administrativos. Lo cual resulta paradójico pues existen testimonios de sarajevitas que reivindican precisamente la convivencia de etnias. Sobre todo porque la mayoría tiene antepasados croatas, eslovenos y musulmanes. En cualquier caso, se trata de un conflicto que apenas se entiende hoy, quizá porque ha pasado poco tiempo y porque las heridas aún no están cerradas: cada 11 julio se siguen enterrando los cadáveres de desaparecidos identificados ese año. De este modo, es aún imposible olvidar.

Las fotografías de Gervasio Sánchez se han encargado de documentar la evolución de ese dolor. Desde las imágenes de Sarajevo: El cerco que recogían el dolor del presente, lo que significa verdaderamente la cotidianidad de la guerra hasta Sarajevo 1992-2008 que constituye el testigo del paso del tiempo en un lugar donde, veinte años después, las heridas aún no están curadas. Es precisamente en este último libro donde parece completarse el círculo, la dinámica del dolor del ser humano ante el conflicto: la guerra estalla, la gente muere o queda gravemente herida, el tiempo pasa y la ciudad vuelve a su rutina pero la mirada del pueblo no puede engañar porque en su memoria ese dolor por el hijo, el padre o el hermano perdido en el absurdo de la guerra está presente.

En el libro Sarajevo 1992-2008, Gervasio Sánchez retoma las historias que fotografió durante los más de nueve meses que vivió en Sarajevo durante el cerco.

${ }^{24}$ Entrevista inédita realizada por Alicia Parras a Gervasio Sánchez en Aranjuez el 2 de julio de 2012 . 
Ahora su obra es un maravilloso testigo y una valiosa obra de documentación que confirma la capacidad que tiene el ser humano de intentar superar las huellas físicas y psicológicas de la guerra. Sin embargo, ¿tenía el fotógrafo esa conciencia de estar realizando un trabajo documental? ¿Por qué volver a Sarajevo dieciséis años después? La razón principal por la que volví fue porque yo necesitaba ver Sarajevo con otros ojos. Sentir que mi balanza anímica se equilibraba y dónde había imágenes duras del conflicto y brutales de la guerra de repente había imágenes de la vida. Esa fue la razón. Si se trataba de un trabajo de documentación o no pues sinceramente no me lo planteé. No obstante, si que busqué un formato de trabajo que tenía mucho de documental, es decir, donde antes había una ciudad destruida ahora habia una ciudad reconstruida, y para verlo habia que buscar determinadas imágenes y colocarlas en los mismos encuadres y hacer un trabajo de documentación pero yo al principio ni siquiera me lo planteé. Era algo, insisto, para equilibrar mi balanza anímica, para sentirme bien en una ciudad que me habia hecho sufrir mucho durante el cerco. ${ }^{25}$ El hecho de que, además, las fotografías tomadas durante el asedio estén en blanco y negro en contraposición a las tomadas en 2008 , en color, ayudan a reforzar el carácter documental de la obra.

Pero sin duda, lo más interesante es descubrir que ha sido de las personas fotografiadas entre 1992 y 1994. Preguntas que se quedaron sin respuesta allá por 1995 cuando Sarajevo: el cerco fue publicado. ¿Qué ocurrió con los padres de Nermin Divovic, aquel niño que desafiaba a la cámara de Gervasio con una bola de nieve meses antes de ser disparado mortalmente por un francotirador? Gracias a este libro podemos saber que tuvieron dos hijos más después de la guerra.

En el anterior punto mencionábamos la trágica historia del bebé Nalena Skorupan fallecida con apenas unos meses de vida debido al impacto de un proyectil contra su casa cuando estaba al cuidado de su tía ${ }^{26}$. Mirsada murió en el acto decapitada y Nalena falleció dos días después en el hospital a causa de las múltiples heridas. Cuando Gervasio vuelve a Sarajevo en 2008 logra localizar al tío de Nalena y marido de Mirsada, Mirsad Demirovic e incluso a la madre de esta niña, Elvedina, que también había perdido a su marido cuando se encontraba embarazada de Nalena y a su madre a causa de un infarto ese mismo año. Hoy tiene otros tres hijos pero confiesa que nunca perdonará a los culpables ${ }^{27}$. Mirsad regaló a Gervasio una foto de la niña en brazos de su tía horas antes de morir (después de haber visto la foto tantas veces

${ }^{25}$ Entrevista inédita realizada por Alicia Parras a Gervasio Sánchez en Aranjuez el 2 de julio de 2012.

${ }^{26}$ Véase página 97 del presente artículo.

27 SÁNCHEZ, Gervasio: ¿Cuándo acaba una guerra? http://blogs.heraldo.es/gervasiosanchez/ $10 / 07 / 2010$ 
de la niña destrozada y ver esta otra del bebé con su sonrisa, con su mirada... te llena de satisfacción. Ves a la cría cómo era no como la dejaron). ${ }^{28}$

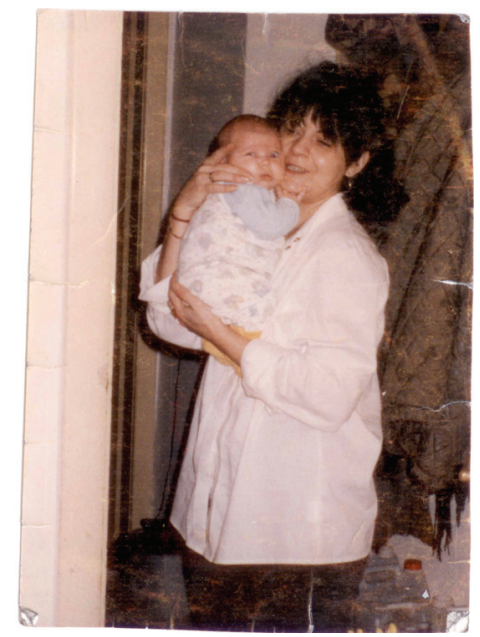

Nalena Skorupan en brazos de su tía Mirsada

Gervasio Sánchez consiguió así cerrar un círculo. Y no solo con esta historia sino con la mayoría de ellas. Logró contactar con muchos de los protagonistas de Sarajevo: el cerco, a veces preguntando por las calles cercanas a dónde tomo la fotografía concreta, otras por casualidad, otros porque durante todos esos años había mantenido el contacto y también hubo otros a los que no logró localizar.

\section{CONCLUSIONES}

La idea del presente artículo es intentar entender a través de la fotografía documental, y más concretamente del trabajo de Gervasio Sánchez, lo que supuso la guerra de Bosnia.

Para poder entender esta guerra nos hemos remontado históricamente a lo que fue el desmembramiento de la antigua Yugoslavia: cómo las seis repúblicas y las dos regiones obtuvieron con mayor o menor dificultad, su independencia. De todas las repúblicas, el caso más conflictivo, debido a que ninguna de las tres etnias era mayoritaria, fue el caso, de la República de Bosnia-Herzegovina, este marco histórico explicado brevemente en el artículo, nos sirve para comprender, lo que supuso

${ }^{28}$ Entrevista inédita realizada por Alicia Parras a Gervasio Sánchez en Aranjuez el 2 de julio de 2012 . 
Sarajevo, y por qué fue una ciudad sitiada y bombardeada, que luego podemos contemplar en las fotografías.

Pero la historia es solo la secuencia de los hechos, la literatura en cambio es la recreación de las imágenes, las vivencias y los sentimientos personales, gracias a la palabra que nos explican lo que realmente ocurrió y gracias a la obra de dos de los mejores escritores contemporáneos de la Antigua Yugoslavia: Ivo Andric, y Danilo Kis.

Y la guerra la conocemos siempre, no solo a través de sus protagonistas y los que la sufren, sino a través de quién nos la hace llegar a través de las imágenes, y quienes nos relatan los hechos, que son los periodistas. En cualquier caso, se trató de una guerra bien cubierta por los medios de comunicación, pero sin presencia de intelectuales de otros países que se conmovieran con lo que veían y se solidarizasen con las victímas del conflicto. Fue, por tanto, una guerra muy mediática, pero con informaciones escasas en el valor de la noticia y, en muchos casos, manipuladas y tergiversadas por los intereses de la comunidad Serbia. Y si la presencia internacional fue escasa en intelectuales, también hicieron oídos sordos las grandes potencias occidentales y los organismos internacionales, que apenas actuaron, y de este modo, asistimos a las imágenes, que pese al dolor que transmitían, produjeron una gran pasividad en todo el mundo.

Los medios de comunicación contaban con libertad para moverse e informar, existían ya grandes avances en cuanto a nuevas tecnologías, pero si preguntamos a la mayoría de los europeos cultos que contemplamos esta información, en realidad pocos son capaces de explicar qué fue verdaderamente lo que ocurrió.

Curiosamente, el trabajo de un reportero freelance, que contaba con sus propios medios, hablamos de Gervasio Sánchez, ha sido el más eficaz y profundo en cuanto a la profundidad de un trabajo bien hecho sobre el terreno. Hoy en día quizá sea el que mejor demuestre lo que sucedió y lo que realmente se vivió en Sarajevo, y quedará para la historia como el documento que nos explique la guerra de Bosnia, como en la literatura, Un puente sobre el Drina, de Ivo Andric.

\section{BIBLIOGRAFÍA}

ANDRIC, Ivo. Un puente sobre el Drina. Madrid, Debate, 1999.

BOURKE-WHITE, Margaret: Dear Fatherland, rest quietly: a report on the collapse of Hitler's "thousand years" New York .Simon and Schuster, 1946

FONTANA, Josep. Por el bien del Imperio. Una historia del mundo desde 1945. Barcelona, Ediciones de Pasado Presente, 2011.

FREUND, Gisèle. La fotografia como documento social. Barcelona, Gustavo Gili, 1976

GOYTISOLO, Juan. Cuaderno de Sarajevo. Anotaciones de un viaje a la barbarie. Madrid, El País-Aguilar, 1993. 
KIS, Danilo. Una tumba para Boris Davidovich. Prólogo de Joseph Brodsky. Barcelona, Acantilado, 2006.

NAVARRO, Pepe: Sarajevo humano. Palabras, retratos e imágenes.111 entrevistas a sus habitantes después de la guerra. Barcelona. Blume, 1999.

RODRÍGUEZ CELA, Julia y PARRAS PARRAS, Alicia. "El tratamiento documental en la fotografía de prensa: ante el dolor de los demás y el conflicto de los otros". Revista General de Información y Documentación, Vol. 20, 2010.

SÁNCHEZ, Gervasio: Sarajevo: El Cerco. Editorial Complutense, Madrid, 1994.

SÁNCHEZ, Gervasio: Sarajevo 1992-2008. Blume, Madrid, 2009.

SONTAG, Susan: Ante el dolor de los demás. Santillana, Madrid, 2007.

NOTA: la autoría de las imágenes mostradas en el presente artículo pertenece a Gervasio Sánchez. 